\title{
A numerikus számítások szerepe a műszaki modellekben
}

\author{
D. SIPOS
}

University of Debrecen, dorasipos@eng.unideb.hu

Abstract. Application of numerical methods and stochastic approach should have a bigger role in the Mathematics programme of the secondary schools. Studying economic and engineering problems leads to better understanding of the significance of mathematical models in practice. In our mini-course we introduce several topics related to mathematical modelling of systems and processes to present the applicability of mathematical calculation methods in the everyday life.

\section{Bevezetés}

A középiskolai matematikaoktatás kevés hangsúlyt helyez a mérnöki szemlélet formálására, ezen belül a közelítő számítások, becslés, mérés, interpoláció kérdéskörre, és általában a numerikus módszerekre. Az analitikus megközelítés kizárólagossága, a pontos érték meghatározása nem formálja kellőképpen a műszaki modellek és problémamegoldáshoz szükséges szemléletmódot.

„A numerikus számítások szerepe a múszaki modellekben” címmel egy olyan 2-3 órás középiskolai foglalkozást készítettünk elő, melyen számos egyszerű példát mutatunk be becslésre és közelítésre, és bemutatunk olyan feladatokat is, melyek rávilágítanak a statisztikai következtetések szerepére is.

A foglalkozás célja a felvetett kérdéskörök bemutatása, a felvetődő kérdésekre a gyakorlatban adott válaszok ismertetése, a saját tapasztalatokra, példákra való rákérdezés. A foglalkozás része, a tanulók gondolkodásmódjának felmérése célirányos kvíz kérdésekkel. A válaszok megbeszélése elvezet a tárgyalni kívánt témákhoz. Ezt követi a tanulók számára áttekinthető, szemléletformáló példák bemutatása. A foglalkozásokon a tanulók aktív részvétele a cél, az ötletek, meglátások megfogalmazása, a folyamatos interakció.

\section{A foglalkozás témakörei}

A mindennapi mérnöki munka része a mérés, adatelemzés és a becslés. Egy rendszert vagy folyamatot vizsgálva egy paraméter vagy jellemző értéke becsülhető a tapasztalat, a szaktudás birtokában, így a matematikai számítással kapott eredményt a felhasználó kontrollálni tudja (és ezt meg is kell tennie). A becslés témakör a matematikaoktatás során általános iskolában jelenik meg, később azonban nem kap kellő hangsúlyt, így ennek a lépésnek a fontossága nem tudatosul a diákokban. Emellett a tanulók képe a pontos érték, a kerekített érték, a mérési pontosság, az értékes jegyek száma fogalmakról általában nem tiszta. A numerikus számítások, a mérés, az adatelemzés szerepének bemutatása hasznos abban a tekintetben is, hogy segít a problémák új megközelítési módjának kialakításában. 
A műszaki pálya iránti érdeklődés felkeltésében és a sikeres pályaválasztásban fontos, hogy a középiskolások kellő tájékozottsággal rendelkezzenek a mérnöki területekről, tevékenységekről, gondolkodásmódról. A szakgimnáziumok sok tekintetben jól felkészítik a mérnöki pályára készülő hallgatókat a szakmai tárgyakat keretében, a gimnáziumokban viszont ez nem valósul meg. A normál tananyag tanulásával a tanulók kevés tapasztalatot tudnak gyűjteni ezen a műszaki témakörök terén.

A felsőoktatási intézmények sokféle módon tudnak segíteni az érdeklődés felkeltésében, ezek közül egyértelműen a személyes találkozás, a tanulókkal való beszélgetés a leghatékonyabb a tapasztalatok szerint. A középiskolásokkal való találkozásnak több apropója lehet, ilyenek az egyetemen tett látogatások, a középiskolákban tartott szakmai előadások, bemutatók, szakkörök, foglalkozások.

A Debreceni Egyetem Műszaki Kar Műszaki Alaptárgyi Tanszék jó pár évvel ezelőtt kezdte el érdeklődésfelkeltő, tudománynépszerűsítő, interaktív foglalkozások kidolgozását és megtartását olyan matematikai, geometriai, informatikai és műszaki témakörökben, melyek kapcsolódnak a DE Műszaki Karon fő folyó képzésekhez [1].

„A numerikus számítások szerepe a műszaki modellekben” című foglalkozás 4 témakörre koncentrál, ezek a becslés, a pontosság, a számok és a digitális értékek.

\subsection{Becslés}

A közoktatásban az alsóbb osztályokban megjelenik a becslés fogalma matematika órákon, de a becslés, illetve a számolás eredményének kontrollálása nem válik a feladat megoldási kultúra részévé. Még egyetemistáknál is tapasztalható, hogy nyilvánvalóan rossz megoldást is elfogadnak, mivel nem érzik a szakmai probléma józan ésszel való átgondolásának szükségességét.

A mérnöki munka szerves része a mérés, adatelemzés és a becslés. Ezek a tevékenységek nagyon különböző módon jelennek meg például egy építőmérnök és egy villamosmérnök munkájában, de az minden mérnöki tevékenységben közös, hogy egy rendszert vagy folyamatot vizsgálva a kérdéses paraméter, jellemző értéke becsülhető a tapasztalat, a szaktudás birtokában, így a matematikai számítással kapott eredményt a felhasználó kontrollálni tudja. Ez a fajta szakmai kontroll a számolás eredményét illetően nem csak azért fontos, hogy az esetleges számolási vagy mértékegységegyeztetési hibákra fény derüljön, hanem azért is, mert a matematikai modellben adódhatnak olyan megoldások, melyek nem megoldásai az eredeti feladatnak.

\subsection{Pontosság}

A tanulók általában nincsenek tisztában a pontos érték, a kerekített érték, a mérési pontosság, az értékes jegyek száma fogalmakkal. Ennek az lehet az oka, hogy a matematikai problémák megoldása során nem térnek ki ezekre a kérdésekre, illetve a feladatok ebből a szempontból egysíkúan vannak megfogalmazva.

Bár a gyakorlatban a mérőrendszer vagy a megfigyelés pontossága határozza meg a számolásba vitt adatok pontosságát - tehát valójában a mennyiségeknek nem a pontos, hanem a becsült értékével 
dolgozunk - addig a matematikai példákban ez a gondolat nem jelentkezik, az „input adatok” minden esetben „pontosnak tűnnek”, melyek alkalmasak a „pontos” eredmény kiszámítására.

A feladatmegoldás végén pedig a pontosnak vélt eredmény kerekítésére kerül sor valamilyen megállapodás szerint. Ráadásul a kerekítés kapcsán gyakran arról beszélnek, hogy „hány tizedesjeggyel kell számolni”, miközben a problémamegoldásban az értékes jegyek számának van jelentősége.

Tapasztalat, hogy egyetemi hallgatók megadnak olyan eredményt, aminek a „látszólagos” pontossága nincs összhangban sem a bemeneti adatok pontosságával, sem az eredmény gyakorlati felhasználásával. Például egy vizsgált gerenda hosszára megadják a 600,42578 cm eredményt, ami azt sugallja, hogy a hosszmérést százezred cm pontossággal el lehet végezni.

A számolások pontosságával kapcsolatban egy másik gondolatot is fel kell vetni, ez pedig a közelítő módszerek alkalmazása, melyek „deklaráltan” nem a pontos értéket adják. A gyakorlatban végzett műszaki számítások többsége közelítő számítás, ezért a szemléletformálás szempontjából hasznos néhány alapvető numerikus módszer tárgyalása az analitikus modellekben végrehajtott pontos számolások mellett. Ennek kapcsán meg lehet beszélni a modellalkotás során alkalmazott egyszerűsítési, elhanyagolási lehetőségeket.

\subsection{Számok}

A matematika órákon a matematikai modellekben való számítássokkal foglalkoznak, a valós rendszerek, folyamatok és a hozzájuk kapcsolt modellek viszonyáról kevés szó esik. Véleményünk szerint ez több problémát is okoz. Egyrészt azt a képet alakítja ki a tanulókban, hogy a matematikának számukra nincs haszna (nem tudják a mindennapi életben hasznosítani), másrészt nem alakul ki a modellalkotás és a modellekben kapott eredmények helyes értékelésének készsége.

A matematikai modellben való számolás egy érdekes vetülete a használt számok köre. Ha egy modell alkalmazásakor nem tisztázzuk, hogy a paraméterek értékei mik lehetnek a modellben, és mik a lehetnek ténylegesen (bemenő vagy kimenő adatként ábrázolva ezeket), a tanulók számára problémát okozhat, hogy melyik számhalmazon kell számolni (valós, racionális, egész).

A feladatok többségében folytonos modellben gondolkodunk, a vizsgált mennyiségek értékkészletének valamilyen intervallumot tekintünk. Ezekben a modellekben a valós számok halmazán dolgozunk (ami egy matematikai absztrakció eredménye), és hallgatólagosan a pontos értékre gondolunk úgy a bemenő adatok, mint az eredmények tekintetében.

A gyakorlatban az adatok mérésből, megfigyelésből származnak. A mérőrendszer felbontásából, illetve a számábrázolási módból adódóan (hány értékes jegyet használunk a tizedes tört alakban) a számolások bemenő adatai valójában diszkrétek, és nem pontos értékek. A problémát tovább bonyolítja, hogy a feladatmegoldás végén a „pontos” értéket megadják tizedes tört alakban (valahány tizedesjegyre kerekítve), így újra diszkrét értékkészlet jelenik meg. 
Itt érdemes megjegyezni, hogy a matematikai mintapéldákban az „egyszerűség kedvéért” gyakran egész számokat adnak bemenetként (könnyebb legyen kiszámolni az eredményt akár fejben is), ami azzal jár, hogy a számológéppel való hatékony számolás készsége nem alakul ki a tanulókban.

A valós (és ezen belül a racionális) számhalmazok bevezetését a matematikai modellalkotás indokolja, a gyakorlatban egy mennyiség megmért és lejegyzett értéke egy véges halmazból kerül ki. Ha például egy 32,84 mm névleges hosszúságú termék gyártása során a tényleges hossz a 32,74 - 32,94 mm tartományba esik, és a hosszmérés eredménye a mérőműszeren 0,01 mm „pontossággal” jeleníthető meg, akkor valójában csak 21 különböző mérési eredmény adódhat: 32,74;32,75;...; 32,94, míg a modellben a változó értékkészlete a [32,74;32,94] intervallum (1. ábra).

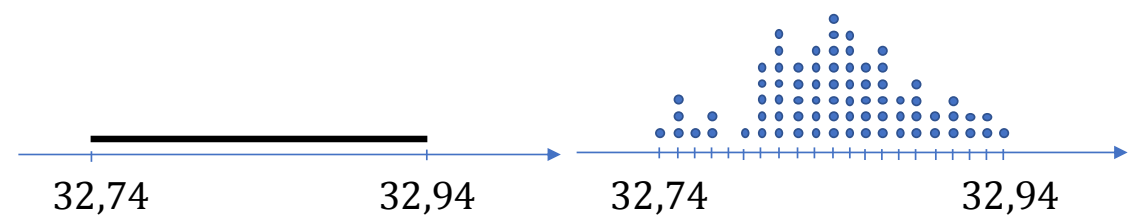

1. ábra. Változó értékkészlete a folytonos modellben, és a mintában szereplő értékek.

Ehhez a kérdéskörhöz kapcsolódik a digitális adattároláshoz szükséges kvantálás (analóg-digitális átalakítás) kérdése, amikor egy mennyiség értéke fizikailag egy intervallum bármelyik elemével egyenlő lehet, a mérőszám azonban csak diszkrét skálán jeleníthető meg az adattárolás módja miatt.

\subsection{Digitális értékek}

A műszaki folyamatok matematikai modellezésében a mennyiségeket az idő folytonos függvényének tekintjük, a digitális méréstechnika és adattárolási mód miatt a gyakorlatban a mennyiségek értékei ezzel szemben csak meghatározott időpillanatokban kvantáltan (diszkrét skálán) állnak rendelkezésre.

A diszkrét idejüség lehet a mintavételezés eredménye, de vannak mennyiségek, melyek csak meghatározott időpillanatokban (valamilyen kiváltó ok hatására) vesznek fel új értéket.

A diszkrét értékek felvétele adódhat egy mennyiség természetéből (például darabszám, gyakoriság), de lehet az adatábrázolási mód következménye (digitális kimenet). Maga a diszkrét időpontokban való mintavételezés is azt eredményezi, hogy az előforduló érékek nem töltenek ki intervallumot (legfeljebb annyi különböző érték állhat elő, amennyi a minta elemszáma).

A rendszertechnikában beszélnek folytonos idejű rendszerekről, ahol a be- és kimenőjel egy időintervallum minden időpontjában értelmezve van, és diszkrét idejű rendszerekről, ahol a be- és kimenőjel egy időintervallumnak csak véges számú pontjában van értelmezve.

Az értékkészletet illetően beszélünk folytonos értékű rendszerekröl, ahol a jel értéke egy intervallum (tartomány) bármely értéke lehet, és diszkrét értékü (kvantált) rendszerekről, ahol jel csak véges sok különböző értéket vehet fel. 


\subsection{Statisztikai alapok}

A statisztika alapgondolatainak bemutatása a középiskolákban hozzájárulhat a matematikai modellekkel kapcsolatos helyes szemléletmód kialakításához. A tantervekben megjelenik a statisztika témakör, a rendelkezésre álló időt helyesen megválasztott példák bemutatásával jól ki lehet használni erre a célra.

Véleményünk szerint a gazdasági és műszaki példák sorával célszerű bemutatni a sztochasztikus szemléletmód szükségességét. Az alapgondolatok között kell szerepelnie annak, hogy a gyakorlatban miért szükséges minden esetben számolni az adatok szóródásával, mi ennek az oka, és hogyan lehet az ilyen jellegű adatokat kezelni. A másik fontos gondolat a paraméterek pontos és becsült értékének viszonya a modellben, ezek becslési módszereinek bemutatása, valamint a változók közti kapcsolat keresésének módja.

\section{A foglalkozás néhány feladata}

\subsection{Becslés}

1. Kb. mennyi az ábrán látható négyzet és a kör területének aránya?

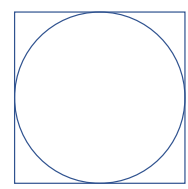

2. Az $\frac{1}{20500} \cdot x=\frac{1}{95}$ egyenlet megoldása melyik számhoz áll a legközelebb?

3. Kb. hány fokos szögben emelkedik az ábrán látható út?

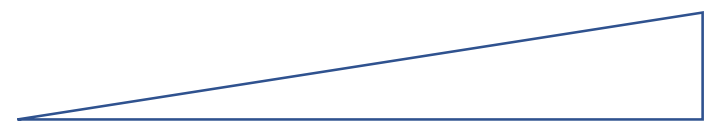

4. Kb. hány köbméteres az ábrán látható ház padlástere?

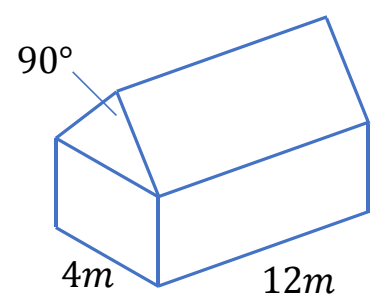


5. Kb. mennyi a képen látható síkidom területe?

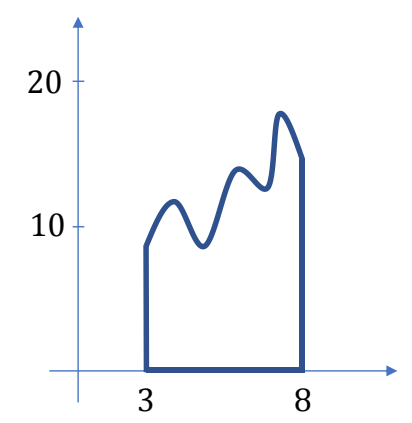

6. Kb. mekkora Portugália területe, ha tudjuk, hogy Németország területe $357.376 \mathrm{~km}^{2}$ ?

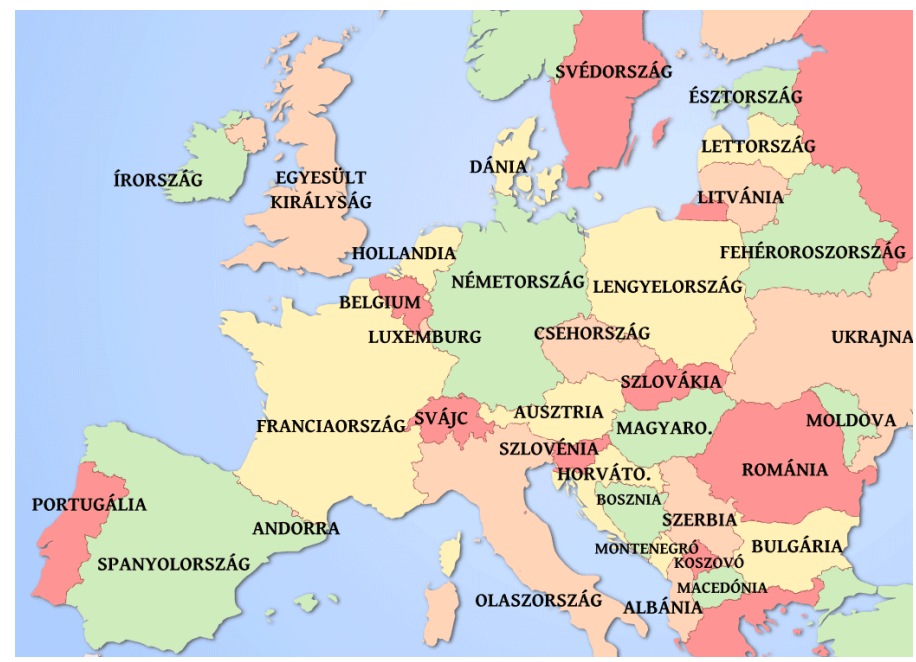

\subsection{Pontosság}

1, Milyen pontossággal tudjuk megmondani azt, hogy egy épület milyen messze van tőlünk. (Feltételezzük, hogy az épület 10-30 m közötti távolságban van.)

2, Egy tárgy anyagának (átlagos) sűrűségét tömeg- és térfogatméréssel állapítjuk meg $\mathrm{g} / \mathrm{cm}^{3}$ egységben. Milyen pontosan kapjuk meg a sűrűséget, ha a tömeget $g$, a térfogatot $\mathrm{cm}^{3}$ pontossággal mérjük?

3, 2 perc körüli időtartamot mérőeszköz nélkül („érzésből”) milyen pontossággal tudunk megmérni?

4, Egy 1,5 $\mathrm{m}^{2}$ felszínű, függőleges falú kád esetén $\mathrm{cm}$ pontossággal tudjuk mérni a vízszint magasságát. Milyen pontosan tudjuk mérni ezzel a vízmennyiség térfogatváltozását? 


\subsection{Számok}

1, Jelölje be a $\sqrt{2}$ helyét a számegyenesen!

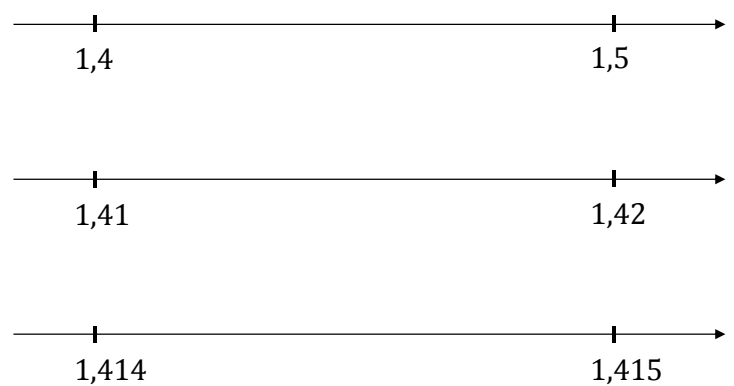

2, Jelölje be a $\pi$ helyét a számegyenesen!

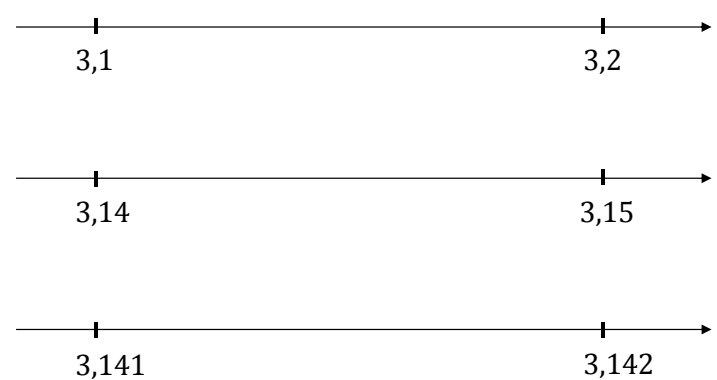

3, Melyik a célszerű megadása a hűtőgép magasságának, ha feltételezzük, hogy a pontos méret $0,6 \cdot \sqrt{10}$ méter?

$$
1,9 \mathrm{~m} \quad 1,90 \mathrm{~m} \quad 1,897 \mathrm{~m} \quad 1,8974 \mathrm{~m} \quad 1,89737 \mathrm{~m}
$$

4, Melyik a célszerű megadása Föld-Hold (átlagos) távolságnak, ami kb. 384402 km?

$$
400000 \mathrm{~km} \quad 384000 \mathrm{~km} \quad 384402,3 \mathrm{~km} \quad 384402,3871 \mathrm{~km}
$$

\subsection{Digitális értékek}

Képzeljük el, hogy

$$
x(t)=0,04 \cdot \sin (440 t)
$$

jelből $2000 \mathrm{~Hz}$ mintavételi frekvenciával, a $t=0$ időpillanatban indulva 11 elemű mintát veszünk, és tegyük fel, hogy a mérés pontos! Adjuk meg a kapott értékeket 6 értékes jegy felhasználásával! Adjuk meg a kvantált értékeket, ha a $[-1,1]$ intervallumot $2^{4}$ intervallumra bontjuk (4 biten ábrázoljuk az eredményt), és az intervallum közepét tekintjük értéknek.

\begin{tabular}{c|c|c|c|c} 
& $t[s]$ & $\begin{array}{c}x(t) \\
\text { formulával }\end{array}$ & $\begin{array}{c}x(t) \\
6 \text { értékes jegy } \\
\text { pontossággal }\end{array}$ & $\begin{array}{c}x(t) \\
\text { kvantált } \\
\text { értékekkel }\end{array}$ \\
\hline 1 & $\frac{0}{2000}=0,0000$ & $0,04 \cdot \sin (0)$ & 0,000000 & 0,025 \\
\hline 2 & $\frac{1}{2000}=0,0005$ & $0,04 \cdot \sin \left(\frac{440}{2000}\right)$ & 0,087292 & 0,075
\end{tabular}




\begin{tabular}{c|c|c|c|c}
3 & $\frac{2}{2000}=0,0010$ & $0,04 \cdot \sin \left(\frac{440 \cdot 2}{2000}\right)$ & 0,170376 & 0,175 \\
\hline 4 & $\frac{3}{2000}=0,0015$ & $0,04 \cdot \sin \left(\frac{440 \cdot 3}{2000}\right)$ & 0,245247 & 0,225 \\
\hline 5 & $\frac{4}{2000}=0,0020$ & $0,04 \cdot \sin \left(\frac{440 \cdot 4}{2000}\right)$ & 0,308296 & 0,325 \\
\hline 6 & $\frac{5}{2000}=0,0025$ & $0,04 \cdot \sin \left(\frac{440 \cdot 5}{2000}\right)$ & 0,356483 & 0,375 \\
\hline 7 & $\frac{6}{2000}=0,0030$ & $0,04 \cdot \sin \left(\frac{440 \cdot 6}{2000}\right)$ & 0,3874866 & 0,375 \\
\hline 8 & $\frac{7}{2000}=0,0035$ & $0,04 \cdot \sin \left(\frac{440 \cdot 7}{2000}\right)$ & 0,399810 & 0,375 \\
\hline 9 & $\frac{8}{2000}=0,0040$ & $0,04 \cdot \sin \left(\frac{440 \cdot 8}{2000}\right)$ & 0,3928662 & 0,375 \\
\hline 10 & $\frac{9}{2000}=0,0045$ & $0,04 \cdot \sin \left(\frac{440 \cdot 9}{2000}\right)$ & 0,366975 & 0,375 \\
\hline 11 & $\frac{1}{2000}=0,0050$ & $0,04 \cdot \sin \left(\frac{440 \cdot 10}{2000}\right)$ & 0,323399 & 0,325
\end{tabular}

\begin{tabular}{c|c}
$\begin{array}{c}\text { Intervallum } \\
\text { végpontok }\end{array}$ & $\begin{array}{c}\text { Intervallum } \\
\text { középpontok }\end{array}$ \\
\hline$-0,400$ & $-0,375$ \\
$-0,350$ & $-0,325$ \\
$-0,300$ & $-0,275$ \\
$-0,250$ & $-0,225$ \\
$-0,200$ & $-0,175$ \\
$-0,150$ & $-0,125$ \\
$-0,100$ & $-0,075$ \\
$-0,050$ & $-0,025$
\end{tabular}

\begin{tabular}{c|c}
$\begin{array}{c}\text { Intervallum } \\
\text { végpontok }\end{array}$ & $\begin{array}{c}\text { Intervallum } \\
\text { középpontok }\end{array}$ \\
\hline 0,000 & 0,025 \\
0,050 & 0,075 \\
0,100 & 0,125 \\
0,150 & 0,175 \\
0,200 & 0,225 \\
0,250 & 0,275 \\
0,300 & 0,325 \\
0,350 & 0,375
\end{tabular}

\section{Köszönetnyilvánítás}

A publikáció elkészítését az EFOP-3.6.1-16-2016-00022 számú projekt támogatta. A projekt az Európai Unió támogatásával, az Európai Szociális Alap társfinanszírozásával valósult meg.

\section{Hivatkozások}

[1] I. Kocsis - I. Papp (2016) A múszaki pálya felé orientáló szakmai foglalkozások középiskolások részére. Matematikát, fizikát és informatikát oktatók XXXL. országos és nemzetközi konferenciája, Székesfehérvár.

[2] D. Sebők-Sipos (2017) A müszaki modellekben alkalmazott numerikus számítások szerepének bemutatása középiskolásoknak tartott ismeretterjesztő foglalkozásokon. Proceedings of the Conference on Problem-based Learning in Engineering Education, Debrecen. 